\title{
Student satisfaction survey: a key for quality improvement in the higher education institution
}

\author{
Anita Kanwar* (1) and Meghana Sanjeeva
}

\section{*Correspondence:}

anita_s_kanwar@yahoo.com

Department of Physics,

Vivekanand Education

Society's College of Arts,

Science and Commerce,

Sindhi Society, Chembur,

Mumbai, Maharashtra

400071, India

\begin{abstract}
India has witnessed a rapid expansion in the higher education institutions and with this fast pace of growth day by day, competition has set in among the institutes. Before taking admission in an institution student assess the facilities and standard of the institution by referring to the website, other admission portals and by taking peer opinion and public perception. Educational institutions around the world are now requesting students'feedback on all elements of academic life in the form of a satisfaction feedback questionnaire. The goal of this research is to describe the development and implementation of a survey to assess undergraduate and postgraduate student satisfaction. The Student Satisfaction Survey is a useful and effective instrument that tries to focus resources on areas, where there is low satisfaction but high importance. This paper gives detailed information about the methodology, calculation and outcome of the exercise utilizing Likert scale analysis. With the recent emerging trends, this innovative method offers flexibility to integrate more parameters, group certain parameters to get feedback on a particular issue and transmute the type of questions with changing environment and structure. The analysis is done using a statistical method. The survey result directly highlights the importance and flexibility of method to evaluate overall satisfaction, satisfaction cognate to a single parameter and satisfaction for questions grouped together underlining some paramount aspects of higher education.
\end{abstract}

Keywords: Higher education institution, Student satisfaction, Feedback, Undergraduate, Postgraduate

\section{Introduction}

The Indian higher education system is the third largest in the world. The higher education institutions are governed by the norms set by the affiliating University based on the guidelines provided by the University Grant Commission (UGC). National Assessment and Accreditation Council (NAAC) has been established to strengthen the education system, to ensure complete transparency, to stimulate the academic environment for promotion of quality of teaching-learning and research in higher education institutions (HEI).

Students are the most important stakeholders of any educational institution. Along with students' progression and placements one of the main indicators of a college's

(c) The Author(s) 2022. Open Access This article is licensed under a Creative Commons Attribution 4.0 International License, which permits use, sharing, adaptation, distribution and reproduction in any medium or format, as long as you give appropriate credit to the original author(s) and the source, provide a link to the Creative Commons licence, and indicate if changes were made. The images or other third party material in this article are included in the article's Creative Commons licence, unless indicated otherwise in a credit line to the material. If material is not included in the article's Creative Commons licence and your intended use is not permitted by statutory regulation or exceeds the permitted use, you will need to obtain permission directly from the copyright holder. To view a copy of this licence, visit http:// creativecommons.org/licenses/by/4.0/. 
progress is the students' level of satisfaction. In India HEIs are not only imparting the required skills and improving the abilities of their graduates but are also concentrating to gratify students' feelings about their scholastic experiences in the institution. There is emphasis on primary activities such as teaching learning, evaluation, research, extension activities, innovation along with emphasis on infrastructure facilities, quality of services, welfare measures for students and staff and overall satisfaction. of overall educational experience.

The vigorous, efficacious and value predicated scholastic system is the backbone of any nation. To progress in the right direction complete knowledge of student diversity, socio economic status, expectations and academic preferences are very useful parameters.

The gratified individual will have greater efficiency and will contribute to further progress of the institution and nation at large. Students who are studying in a higher educational institution seek more quality education and perfection of the system, in terms of approachability of the place, good infrastructure, quality education system, services offered by the institution, additional inputs in the form of value addition and employability enhancement courses etc. As stated by Usman (2010) the infrastructure facilities are becoming important, because these facilities satisfy student's perception, esteem and develop them with all the essentials and capabilities to be an efficacious learner.

HEI's all across the world are increasingly vying for students on a national and international level. They strive to improve student satisfaction to admit and retain students. This can only be accomplished if all of the services that contribute to "academic life" are of sufficient quality. Students satisfaction can be defined as an attitude resulting from an assessment of students' educational experience, services and facilities provided by the institution. Because students are the important internal judges of performance of the institute, student satisfaction surveys are important and help the HEI to improve and adjust accordingly in the landscape of higher education. It also provides satisfaction to the institute of offering quality education.

\section{Literature review}

Mukhtar et. al. (2015) defined Higher education as education received at a college or university level and is regarded as one of the most essential instruments for a nation's individual, social and economic development. Fortino (2012) emphasized that creation of prepared minds of students was the main purpose of higher education. Hence, higher education institutions are increasingly recognizing and are placing greater emphasis on meeting the expectations and needs of their customers, that is, the students as rightly pointed out by DeShields et. al. (2005).

Higher education institutions are facing greater competition to adopt market-oriented methods to separate themselves from their competitors and attract as many students as possible while still meeting the requirements and expectations of present students. As a result, several research studies have been carried out to determine the elements that influence student happiness in higher education.

Elliot and Healy (2001) defined Students' satisfaction as a short term attitude, resulting from an evaluation of a students' educational experiences. It is a multidimensional process that is influenced by a variety of factors. GPA is the most influential factor on student satisfaction, according to Walker-Marshall and Hudson (1999). 
There are personal and institutional factors associated with the concept of student satisfaction. Personal and institutional factors were identified by Appleton-Knapp and Krentler (2006) as two groups of influences on student satisfaction in higher education. Personal factors include age, gender, employment, preferred learning style, and student GPA, while institutional factors include instruction quality, promptness of instructor feedback, clarity of expectation, and teaching style.

Furthermore, teaching ability, curriculum flexibility, university status and prestige, independence, faculty care, student growth and development, student centeredness, campus climate, institutional effectiveness, and social conditions have been identified as major determinants of student satisfaction in higher education by Douglas et. al. (2006) and Palacio et. al. (2002).

Several models and frameworks have been applied by researchers to uplift students' satisfactions in higher education literature. SERVQUAL is a most popular widely used service quality model which has been applied to measure students' satisfaction around the world. SERVQUAL is a questionnaire designed, developed, and tested in the business environment by Parasuraman (1985) to measure service quality and customer satisfaction of a business based on five dimensions: tangibility, reliability, empathy, responsiveness, and assurance. Though widely used in business. It received some criticism from various researchers in higher education literature by scholars.

Elliot and Shin (2002) developed a more comprehensive student satisfaction inventory covering 11 dimensions and 116 indicators to measure the satisfactions of students in the higher education industry.

Weerasinghe et. al. (2017) traces the history of several models for student satisfaction derived from the business and higher education arena.

With the development of higher education in the world, the importance of students' satisfaction has emerged in the literature of higher education. At the beginning, industry based satisfaction models were applied to explain student satisfaction and later developed higher education based models to explain it.

Douglas et. al. (2006) developed the "Service Product Bundle" method to investigate influences on student's satisfaction in higher education, considering 12 dimensions.

Though several models are available, it is difficult to directly use any of them due to the heterogeneous nature of our educational system. In India with maximum diversity of religion, culture, demography, language and education system itself, it is all the more difficult to have a single parameter to finalize student satisfaction.

Therefore, there is a need to design a survey suitable to the specific need of a higher education institute. This study is innovative in its approach as it has designed a survey considering the local needs but to meet the global standards. NAAC has given broad guidelines which are suitable for the broad Indian higher education system.

This study endeavors to analyze student satisfaction, using a survey which is designed to obtain feedback on the administrative practices, college infrastructure, teacher quality and additional facilities on the campus. This exercise additionally aims at resoluteness of paramountcy of a variety of practices which were introduced at college to mentor students predicated on their requisites.

NAAC guidelines are taken as the base for designing the questionnaire for obtaining the feedback which is utilized determinately to analyze Student satisfaction. This 
is also because NAAC is responsible for accreditation of the institution and grading them on a 4-point scale. The questions framed here have direct linkage to the NAAC seven criteria and the corresponding guidelines prescribed from time to time. This paper also highlights the approach, attitude and expectations of students of aided and self-financing courses.

The feedback obtained using google form assesses student satisfaction and experience in the HEI which may lead to better experience leading to overall personality development of the students and will prepare them for the world of work. Another very important observation in this regard is that the students from all socio economic backgrounds prefer better facilities, quality and above all availability of good infrastructures on their campus. Hence most of the questions in the feedback form are predicated on the assessment and quality of the services provided by more minute units/departments of the institution.

\section{Objectives}

- To find out the satisfactory level of the students with regard to important parameters.

\section{Methodology}

\section{Procedure of the development of the tool}

- Four important dimensions viz. Curriculum \& Teaching, Infrastructure Facilities, Student Support and Administrative matters were finalized. As the first step towards this exercise, a sample questionnaire is prepared. The sample questions are extensively based on the NAAC parameters, general outlook, type of services and activities offered by the institution and current scenario of higher education institutions in and around India. Some initial basic demographic questions are framed to know the respondents in terms of stream (Arts, Science, commerce, etc.) opted by the student, course in which student has enrolled (degree, diploma, graduate or post graduate etc.) and gender of the student. All other questions are framed to get responses on the 5-point scale designed using Likert scale as described by Norman (2010), where 1 indicates poor and 5 indicates excellent satisfaction Adnan et al. (2016) and Hayan and Mokhles (2013)

- A number of parameters under each heading were developed but were randomly spread across to get correct responses.

- A pilot study was conducted and some parameters were removed.

- Later the tool was sent to some experts and necessary changes were made and accordingly the parameters were finalized.

- 41 questions were framed for which students were asked to give responses on the 5-point scale using Google form. 


\section{Sample}

A simple random sample was selected. The Population of the students for the institute was around 3500. A sample group from one college having both undergraduate and postgraduate students in all the three streams (Arts, Science and Commerce) and having a minimum of 2 years of experience with the institution was identified and more than 500 students were selected for this study.

\section{Data analysis and findings}

Survey was rolled out and was kept open for a month. After initial responses were received, a gentle reminder was sent to the students who had not responded. Awareness of this survey was created among student groups to get a better response.

The students were administered the survey online and could participate without disclosing their individual identity to avoid any sort of biased responses from the students or any pressure on the student to give biased response.

The demographic questions were not subjected to any statistical analysis. The percentage wise distribution for each question was directly obtained using Google form analysis data. Table 1 shows the set of responses obtained for one academic year for all the sample questions.

1. As we have listed, this innovative method offers flexibility to combine together some certain parameters to get feedback on a particular issue. As an example we will endeavour to analyse the academic environment based on inputs from teachers on the basis of their efficacy in transaction of curriculum, approachability, ability to provide additional skill set and knowledge through association activities, career guidance and fairness in examination. For this purpose, we will analyze question number 3, 27, 28, 29, 30, 32 and 34. Table 2 gives responses to obtained effectiveness of the teachers using part of the questionnaire that is using only above listed questions (Fig. 1).

2. Similarly, to find the quality of library services and its effectiveness, question numbers 11 to 16 are combined together and analyzed. Table 3 gives responses obtained to analyze the quality and effectiveness of library services.

3. Individual parameter effectiveness can be obtained by analyzing individual questions related to the concerned parameter. As an example question number 40 gives overall perception and satisfaction level of students in terms of support which is provided for cultural activities. Here we have matched excellent response with complete satisfaction, very good response with mainly satisfied, good response with just satisfied, average with partially satisfied and poor response with not satisfied. Responses obtained for this aspect show that 11\% students are completely satisfied, $25 \%$ are mainly satisfied, $40 \%$ are just satisfied, $18.4 \%$ are partially satisfied and $5.6 \%$ are not satisfied at all. The only restriction is sample size should be large enough to get the true picture of satisfaction level as highlighted by Solinas et. al. (2012) and Silva and Fernandes (2012). The sample size taken here is more than 500 outgoing students (Figs. 2 and 3). 
Table 1 Responses obtained from the students on 5-point scale

\begin{tabular}{|c|c|c|c|c|c|c|}
\hline No. & $\begin{array}{l}\text { Questions related to parameter } \\
\text { Weightage }\end{array}$ & $\begin{array}{l}\text { Excellent } \\
5\end{array}$ & $\begin{array}{l}\text { Very good } \\
4\end{array}$ & $\begin{array}{l}\text { Good } \\
3\end{array}$ & $\begin{array}{l}\text { Average } \\
2\end{array}$ & $\begin{array}{l}\text { Poor } \\
1\end{array}$ \\
\hline 1 & Admission procedure followed & $9 \%$ & $24 \%$ & $40 \%$ & $20 \%$ & $7 \%$ \\
\hline 2 & Clarity of notices and guidelines & $11 \%$ & $29 \%$ & $41 \%$ & $17 \%$ & $3 \%$ \\
\hline 3 & Teaching staff approachability & $27 \%$ & $38 \%$ & $29 \%$ & $5 \%$ & $1 \%$ \\
\hline 4 & Promptness in office service & $8 \%$ & $20 \%$ & $40 \%$ & $23 \%$ & $9 \%$ \\
\hline 5 & Fairness and transparency in rules & $16 \%$ & $35 \%$ & $36 \%$ & $9 \%$ & $4 \%$ \\
\hline 6 & Financial support given to needy & $8 \%$ & $23 \%$ & $44 \%$ & $20 \%$ & $6 \%$ \\
\hline 7 & General discipline in the college & $22 \%$ & $35 \%$ & $35 \%$ & $7 \%$ & $2 \%$ \\
\hline 8 & Gender equality & $30 \%$ & $36 \%$ & $28 \%$ & $6 \%$ & $1 \%$ \\
\hline 9 & Security provided in campus & $16 \%$ & $35 \%$ & $38 \%$ & $9 \%$ & $3 \%$ \\
\hline 10 & College schedule (exams and other) & $13 \%$ & $28 \%$ & $40 \%$ & $15 \%$ & $5 \%$ \\
\hline 11 & Library collection (books and other) & $23 \%$ & $35 \%$ & $31 \%$ & $9 \%$ & $2 \%$ \\
\hline 12 & Library staff approachability & $20 \%$ & $35 \%$ & $35 \%$ & $9 \%$ & $2 \%$ \\
\hline 13 & Promptness in library service & $20 \%$ & $30 \%$ & $38 \%$ & $11 \%$ & $2 \%$ \\
\hline 14 & Library and reading room facility & $22 \%$ & $35 \%$ & $30 \%$ & $11 \%$ & $3 \%$ \\
\hline 15 & College web site & $9 \%$ & $25 \%$ & $36 \%$ & $19 \%$ & $11 \%$ \\
\hline 16 & Internet facility (E-resource center) & $7 \%$ & $19 \%$ & $30 \%$ & $24 \%$ & $19 \%$ \\
\hline 17 & Classrooms, labs, computers etc. & $12 \%$ & $26 \%$ & $38 \%$ & $19 \%$ & $5 \%$ \\
\hline 18 & Forum hall and AV room & $12 \%$ & $28 \%$ & $43 \%$ & $12 \%$ & $5 \%$ \\
\hline 19 & Sports facilities (ground/gymkhana) & $9 \%$ & $22 \%$ & $39 \%$ & $20 \%$ & $11 \%$ \\
\hline 20 & Common room facility & $3 \%$ & $15 \%$ & $35 \%$ & $25 \%$ & $22 \%$ \\
\hline 21 & Canteen facility & $4 \%$ & $11 \%$ & $28 \%$ & $31 \%$ & $27 \%$ \\
\hline 22 & Wash rooms & $4 \%$ & $14 \%$ & $37 \%$ & $26 \%$ & $18 \%$ \\
\hline 23 & Safe drinking water & $7 \%$ & $18 \%$ & $39 \%$ & $25 \%$ & $11 \%$ \\
\hline 24 & Emergency medical help & $7 \%$ & $22 \%$ & $48 \%$ & $17 \%$ & $6 \%$ \\
\hline 25 & Amenities for physically challenged & $13 \%$ & $35 \%$ & $39 \%$ & $11 \%$ & $2 \%$ \\
\hline 26 & Hostel facility & $3 \%$ & $13 \%$ & $49 \%$ & $19 \%$ & $16 \%$ \\
\hline 27 & Quality of knowledge imparted & $32 \%$ & $40 \%$ & $24 \%$ & $4 \%$ & $1 \%$ \\
\hline 28 & Activities of department associations & $15 \%$ & $26 \%$ & $43 \%$ & $13 \%$ & $3 \%$ \\
\hline 29 & Mentoring by class coordinators & $20 \%$ & $30 \%$ & $39 \%$ & $9 \%$ & $3 \%$ \\
\hline 30 & Career guidance provided & $19 \%$ & $35 \%$ & $33 \%$ & $8 \%$ & $4 \%$ \\
\hline 31 & Placement support & $17 \%$ & $23 \%$ & $34 \%$ & $15 \%$ & $11 \%$ \\
\hline 32 & Soft skill guidance provided & $11 \%$ & $26 \%$ & $37 \%$ & $18 \%$ & $8 \%$ \\
\hline 33 & Counseling cell & $7 \%$ & $24 \%$ & $48 \%$ & $15 \%$ & $6 \%$ \\
\hline 34 & Fairness in conduct of exam & $22 \%$ & $37 \%$ & $33 \%$ & $7 \%$ & $2 \%$ \\
\hline 35 & Result declaration & $12 \%$ & $32 \%$ & $40 \%$ & $13 \%$ & $3 \%$ \\
\hline 36 & Cultural activities (forum time) & $28 \%$ & $32 \%$ & $27 \%$ & $10 \%$ & $3 \%$ \\
\hline 37 & Sports and trekking club activities & $15 \%$ & $24 \%$ & $39 \%$ & $17 \%$ & $5 \%$ \\
\hline 38 & Activities by NSS, outreach cell & $9 \%$ & $24 \%$ & $43 \%$ & $19 \%$ & $5 \%$ \\
\hline 39 & External linkages & $6 \%$ & $16 \%$ & $29 \%$ & $23 \%$ & $26 \%$ \\
\hline 40 & Support for cultural activities & $11 \%$ & $25 \%$ & $40 \%$ & $18 \%$ & $6 \%$ \\
\hline 41 & Social activities conducted & $13 \%$ & $34 \%$ & $42 \%$ & $10 \%$ & $2 \%$ \\
\hline
\end{tabular}


Table 2 Responses to obtained effectiveness of the teachers

\begin{tabular}{llccccc}
\hline Q. No. & Questions & Excellent & Very good & Good & Average & Poor \\
& Weightage & $\mathbf{5}$ & $\mathbf{4}$ & $\mathbf{3}$ & $\mathbf{2}$ & $\mathbf{1}$ \\
\hline 1 & Teaching staff approachability & $27 \%$ & $38 \%$ & $29 \%$ & $5 \%$ & $1 \%$ \\
2 & Quality of knowledge imparted & $32 \%$ & $40 \%$ & $24 \%$ & $4 \%$ & $1 \%$ \\
3 & Activities of department associations & $15 \%$ & $26 \%$ & $43 \%$ & $13 \%$ & $3 \%$ \\
4 & Mentoring by class coordinators & $20 \%$ & $30 \%$ & $39 \%$ & $9 \%$ & $3 \%$ \\
5 & Career guidance provided & $19 \%$ & $35 \%$ & $33 \%$ & $8 \%$ & $4 \%$ \\
6 & Soft skill guidance provided & $11 \%$ & $26 \%$ & $37 \%$ & $18 \%$ & $8 \%$ \\
7 & Fairness in conduct of exam & $22 \%$ & $37 \%$ & $33 \%$ & $7 \%$ & $2 \%$ \\
\hline
\end{tabular}

Table 3 Responses obtained to find quality and effectiveness of library services

\begin{tabular}{llccccr}
\hline Q. No. & Questions & Excellent & Very good & Good & Average & \multicolumn{1}{c}{ Poor } \\
& Weightage & $\mathbf{5}$ & $\mathbf{4}$ & $\mathbf{3}$ & $\mathbf{2}$ & $\mathbf{1}$ \\
\hline 1 & Collection of library books & $23 \%$ & $35 \%$ & $31 \%$ & $9 \%$ & $2 \%$ \\
2 & Library staff approachability & $20 \%$ & $35 \%$ & $35 \%$ & $9 \%$ & $2 \%$ \\
3 & Promptness in library service & $20 \%$ & $30 \%$ & $38 \%$ & $11 \%$ & $2 \%$ \\
4 & Library and reading room facility & $22 \%$ & $35 \%$ & $30 \%$ & $11 \%$ & $3 \%$ \\
5 & College web site & $9 \%$ & $25 \%$ & $36 \%$ & $19 \%$ & $11 \%$ \\
6 & Internet facility (E-resource center & $7 \%$ & $19 \%$ & $30 \%$ & $24 \%$ & $19 \%$ \\
\hline
\end{tabular}

Table 4 Statistical analysis of data obtained for feedback

\begin{tabular}{llll}
\hline Table no. & Mean & Standard deviation & $\begin{array}{l}\text { Coefficient } \\
\text { of variation }\end{array}$ \\
\hline Table 1 & 3.27 & 2.90 & 0.89 \\
Table 2 & 3.59 & 3.21 & 0.89 \\
Table 3 & 3.36 & 3.01 & 0.89 \\
\hline
\end{tabular}

\section{Results and observations}

The statistical analysis of above data gives the following result (Table 4).

The odd Likert scale has a tendency to give a result in the center scale. Table 4 shows a low standard deviation means that most of the numbers are close to the average. Coefficient of variation tells us about the variability of data. The lower the value of the coefficient of variation, the more precise is the estimate. Although here in all the cases results are pretty good and precise.

The above Table 4 of statistical analysis also indicates that the overall feedback obtained for the institution is Good. The teacher's effectiveness in delivering the task assigned to them is more towards a very good category. The Quality of library services are also good. 


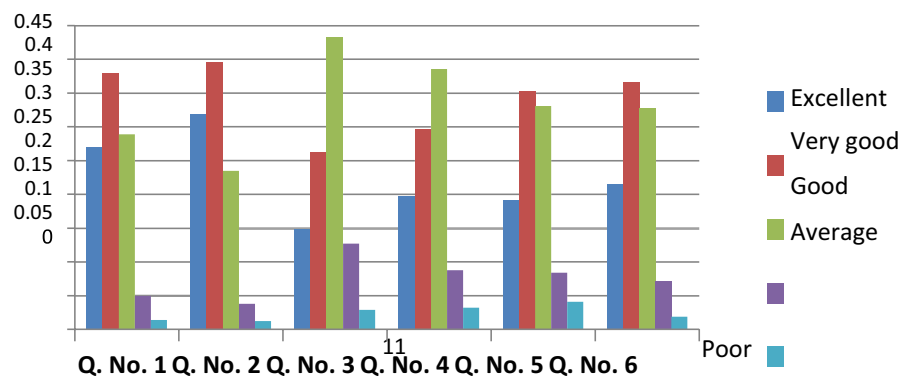

Fig. 1 Graphical representation of the responses obtained for the teacher's effectiveness

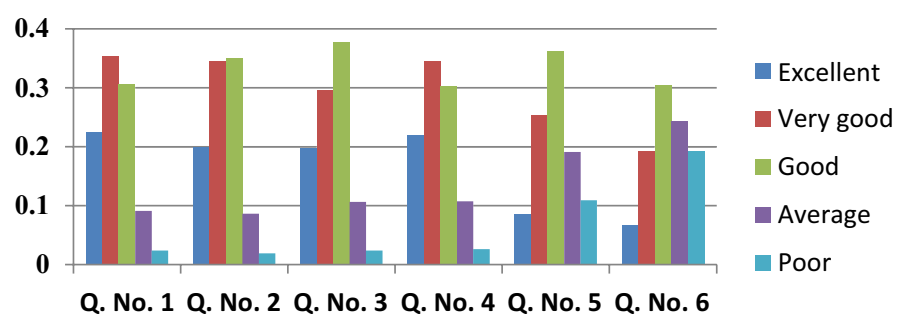

Fig. 2 Graphical representation of effectiveness of library services

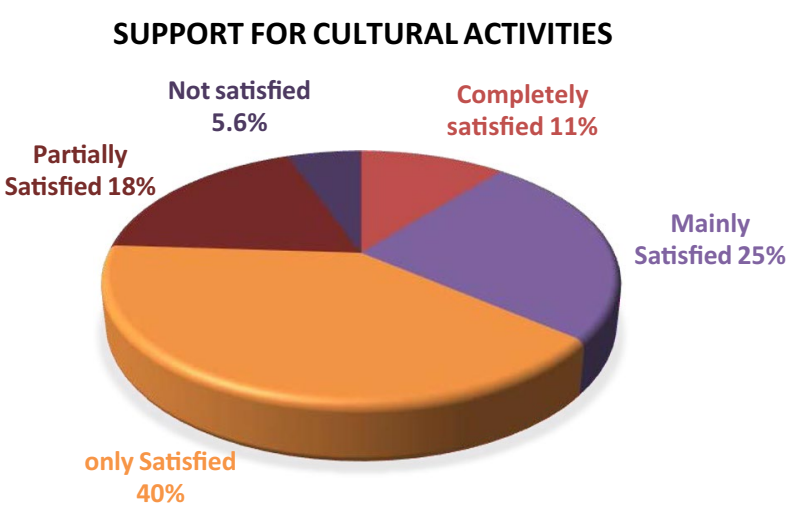

Fig. 3 Graphical representation of responses received for support provided for cultural activities

\section{Discussion}

Another important outcome of this activity is if any institution would want to improve the satisfaction of students in the future, they can analyze the individual parameter responses and some reforms and corrective measures can be introduced. It is the responsibility of the institution to analyze, understand and act on that understanding to improve. Since most of the students had rated quality of office services at a lower level, an Enterprise Resource Planning (ERP) packages can be purchased by the institution to increase the efficiency. Similarly, hostel facilities can be extended to students who are in dire need. 
In another attempt, students were made aware of the objectives and intended learning outcomes of various parameters and then feedback was taken. This exercise also resulted in improvement of the satisfaction level of the students.

\section{Conclusion}

The students' satisfaction and the whole exercise is an innovative method to obtain students' feedback on their academic experience, perceptions and expectations from the higher education institution and finally to assess their satisfaction level. It contributes in understanding student's perception, likes and dislikes and more importantly which educational experience they think of as the most important and which facilities require improvement. The method devised to obtain feedback of students of HEI is very innovative, generic, flexible and easy to adopt by any higher education institution. The questions can be changed and altered based on the requirements of the institution. Various interpretations can be obtained using this technique.

One survey analysis is capable of highlighting many parameters and aspects of higher education institutions. This analysis helps us in determination of parameters which require higher levels of improvement and changes to offer students greater levels of satisfaction. It also helps us in assessing the parameters, where institutions are strong and which can become their strengths. It provides information about actions that can be taken to maintain high levels of satisfaction and improve student learning experiences in the institution. Higher satisfaction level will definitely contribute to better outcomes.

Each question in the questionnaire highlights different aspects of an underlying perception. If few questions are combined together and even Likert scale is used, a reasonably accurate measure of the satisfaction can be obtained and effectiveness of that parameter can be analyzed easily. For instance, Teacher quality in imparting curriculum and giving extra inputs and effectiveness of library services is analyzed in the observation. If this method is used on a regular basis it may provide many insights into satisfaction level of students, changes in student priority, Quality of teachers, factors that really contribute to students' satisfaction. The study also emphasizes that there is a need to make students aware of objectives and intended learning outcomes. It can help administrators to understand the relative importance and accordingly plan improvement in facilities and resources.

The method developed is a useful tool for selecting the most efficient parameters which help in improvement of experience, which leads to satisfaction. The facilities and services of organizations can then be improved to maximize efficiency. This study presents an easy, reliable and complete quality assessment method to obtain student feedback with no additional cost for any software purchase or training.

Abbreviations

UGC: University Grant Commission; NAAC: National Assessment and Accreditation Council; HEl: Higher education institutions; GPA: Grade point average; ERP: Enterprise Resource Planning.

Acknowledgements

We are thankful to National Assessment and Accreditation Council, Bangalore for initiating the idea of Student Satisfaction for colleges. 


\section{Authors' contributions}

The first author has been instrumental in the conceptualization, design and development of the tool and the analysis of the research results. The second author has contributed in the manuscript of the paper. Both authors read and approved the final manuscript.

\section{Funding}

No funding received.

\section{Availability of data and materials}

All the supporting files are uploaded on the Journal Portal.

\section{Declarations}

\section{Competing interests}

The authors declare that they have no competing interests.

Received: 19 April 2021 Accepted: 12 January 2022

Published online: 04 March 2022

\section{References}

Adnan, A., Mohamed, A., Tarek, A., Mun, S., \& Hosny, H. (2016). Measuring student satisfaction with performance enhancement activities: Evidence from business education. International Journal of Information and Education Technology, 6(10), 741-753.

Appleton-Knapp, S., \& Krentler, K. (2006). Measuring student expectations and their effects on satisfaction: The importance of managing student expectations. Journal of Marketing Education, 28(3), 254-264.

DeShields, O., Kara, A., \& Kaynak, E. (2005). Determinants of business student satisfaction and retention in higher education: Applying Herzberg's two-factor theory. International Journal of Educational Management, 19(2), 128-139.

Douglas, J., Douglas, A., \& Barnes, B. (2006). Measuring student satisfaction at a UK university. Quality Assurance in Education, 14(3), 251-267.

Elliott, K., \& Healy, M. (2001). Key factors influencing student satisfaction related to recruitment and retention. Journal of Marketing for Higher Education, 10(4), 1-11.

Elliott, K., \& Shin, D. (2002). Student satisfaction: An alternative approach to assessing this important concept. Journal of Higher Education Policy and Management, 24(2), 197-209.

Fortino, A. (2012). The purpose of higher education: To create prepared minds. Retrieved from https://evolllution.com/ opinions/the-purpose-of-higher-educationto-create-prepared-minds

Hayan, D., \& Mokhles, A. (2013). The impact of service quality on student satisfaction and behavioral consequences in higher education services. International Journal of Economy, Management and Social Sciences, 2(6), 285-290.

Mukhtar, U., Anwar, S., Ahmed, U., \& Baloch, M. A. (2015). Factors effecting the service quality of public and private sector universities comparatively: An empirical investigation. Researchers World, 6(3), 132.

Norman, G. (2010). Likert scales, levels of measurement and the "laws" of statistics. Advances in Health Sciences Education, 15(5), 625-632.

Palacio, A. B., Meneses, G. D., \& Pérez, P. J. P. (2002). The configuration of the university image and its relationship with the satisfaction of students. Journal of Educational Administration, 40(5), 486-505.

Parasuraman, A., Zeithaml, V., \& Berry, L. (1985). A conceptual model of service quality and its implications for future research. Journal of Marketing, 49(4), 41.

Silva, F. H., \& Fernandes, P. O. (2012). Empirical study on the student satisfaction in higher education: Importance-satisfaction analysis. WASET Journal, 6, 1075-1080

Solinas, G., Masia, M., Maida, G., \& Muresu, E. (2012). What really affects student satisfaction? An assessment of quality through a university-wide student survey. Creative Education, 03(01), 37-40.

Usman, A. (2010). The impact of service quality on students' satisfaction in higher education institutes of Punjab. Journal of Management Research, 2(2), 1-11.

Walker-Marshall, A., \& Hudson, C. M. (1999). Student satisfaction and student success in the University System of Georgia. AIR 1999 Annual Forum Paper

Weerasinghe, I. S., Lalitha, R., \& Fernando, S. (2017). Students' satisfaction in higher education literature review. American Journal of Educational Research, 5(5), 533-539.

\section{Publisher's Note}

Springer Nature remains neutral with regard to jurisdictional claims in published maps and institutional affiliations. 